
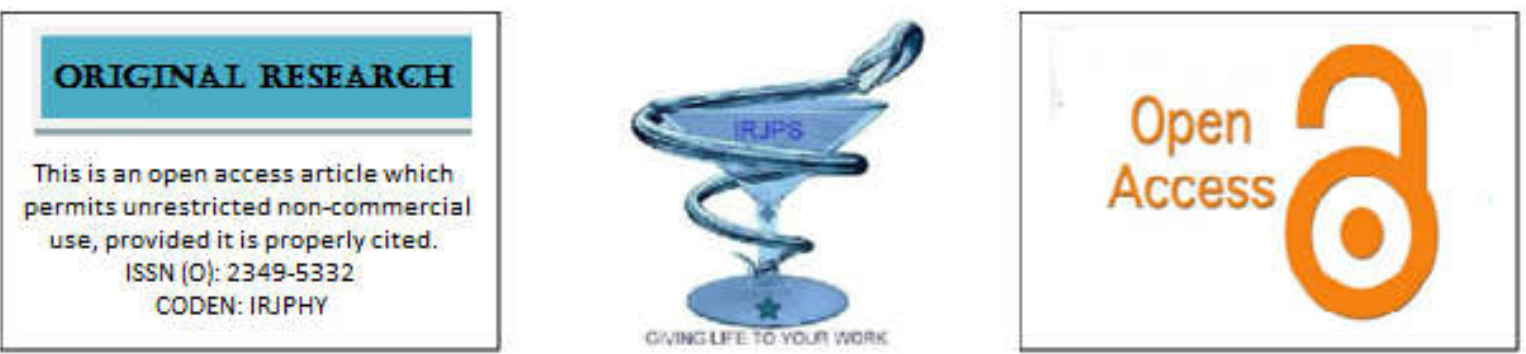

\title{
DETERMINATION AND VALIDATION OF METOPROLOL AND ATORVASTATIN SIMULTANEOUSLY BY RP-HPLC METHOD IN TABLET DOSAGE FORM
}

\author{
Farheen Begum, R. Vani*
}

Department of Pharmaceutical Analysis and Quality Assurance, Shadan Women's College of Pharmacy, Khairatabad, Hyderabad, Telangana, India.

Submitted on: 18.09.19;

Revised on: 22.09.19;

Accepted on: 24.09.19

\begin{abstract}
:
A new simple procedure was developed to simultaneously estimate metoprolol and atorvastatin and also validated by RP-HPLC method in tablet formulation. The separation of the peak was achieved on Inertsil ODS-3 (4.6 ̃-150 $\mathrm{mm}, 5 \mu \mathrm{m}$ ) column using the mixture of Phosphate buffer $\mathrm{pH}$ 3: Methanol 50:50v/v ratio as mobile phase. The injection flow rate was maintained at $1 \mathrm{ml} / \mathrm{min}$, and run time was 10.0 mins. UV detection of both the drugs was achieved at $244 \mathrm{~nm}$ at ambient temperature. The results obtained for this method were in the acceptance criteria and therefore can be employed to estimate metaprolol and Atorvastatin in other dosage forms as well.
\end{abstract}

KEY WORDS: Metoprolol, Atorvastatin, ICH guidelines, method development, validation

Corresponding Author: Dr. R. Vani

Email_id: vrathipelli@gmail.com
Indian Research Journal of Pharmacy and Science; 22(2019)1952-1965; Journal Home Page: https://www.irjps.in DOI: $10.21276 /$ irjps.2019.6.3.6 


\section{INTRODUCTION}

Metoprolol is chemically 1-[4-(2-methoxyethyl )phenoxy]-3-[(propan-2-yl)amino] propan-2-ol as shown in figure 1 . It is selectively $\beta_{1}$ inhibitor, specifically to cardiac cells with minute effect on $\beta_{2}$ receptors. It causes -ve chronotropic and inotropic effects thereby decreasing the cardiac output and exhibits no activity towards membrane stabilization or intrinsic sympathomimetics. ${ }^{1-3}$ and therefore produces reduction on heart-rate and cardiac output in dose dependent manner in normal subjects.

Atorvastatin is chemically (3R,5R)-7-[2-(4fluorophenyl)-3-phenyl-4-(phenylcarbamoyl)-5propan-2-ylpyrrol-1-yl]-3,5-dihydroxyheptanoic acid as shown in figure 2. It is an anti hyperlipedemic agent and is used in the treatment of individuals with high cholesterol levels. ${ }^{4}$ Antihyperlipedemic activity of shown as it competitively inhibits the HMG-CoA reductase enzyme which is involved in cholesterol

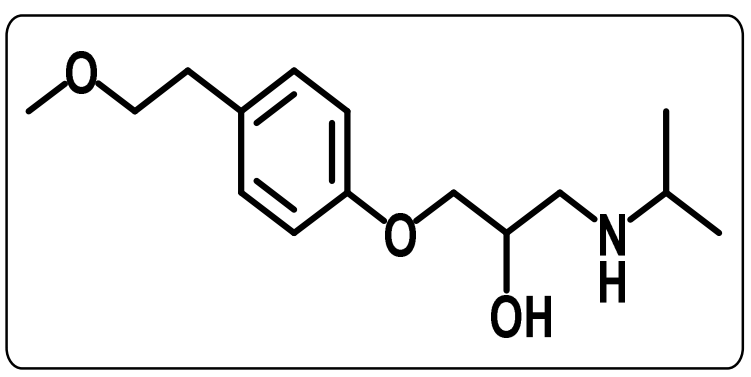

Figure 1: Structure of Metaprolol

\section{MATERIALS AND METHODS}

Metoprolol and Atorvastatin were obtained as gift sample from Pharmatrain lab, Hyderabad, India. Methanol as well as water of HPLC grade was purchased from MERCK. Potasium Dihydrogen phosphate and ortho phosphoric acid was obtained from Finar chemicals and Molychem respectively. synthesis, thereby decreasing the hepatic cholesterol levels and also increase the HDL levels reducing the risk of cardiovascular mortality rate. ${ }^{5,6}$ It is primarily used to prevent coronary heart disease (CHD), myocardial infarction and other cardio vascular disorder.

Literature survey reveals certain developed method to determine metoprolol as well as Atorvastatin which include LC-ESI-MS method ${ }^{7,8}$, HPLC, ${ }^{9-12}$ HPTLC method, ${ }^{13-14}$ UPLC method, ${ }^{15}$ and UV spectroscopic method. ${ }^{16-18}$. There was only one RP-HPLC method reported to estimate metoprolol. ${ }^{19}$ However, there was no reported method to estimate metoprolol and Atorvastatin simultaneously, hence, a new simple, precise and accurate method was developed in the present study to determine the amount of metoprolol and Atorvastatin present in pharmaceutical dosage form.

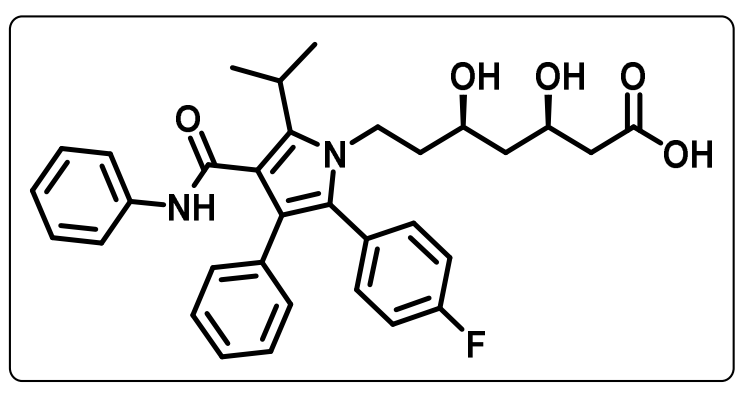

Figure 2: Structure of Atrovastatin

MET XL ATF tablets were purchased from pharmacy.

Instrumentation

HPLC system (WATERS) empowered with 2695 separation module was used for the separation of metoprolol and atorvastatin. Detection was achieved using UV/VIS spectrophotometer (LABINDIA UV 
$12.500^{+}$) where instruments such as $\mathrm{pH}$ meter used was Adwa - AD 10100 and weighing machine belongs to Afcoset ER-1000A.

\section{Method development}

As there was no economical method observed for the determination of metoprolol as well as Atorvastatin simultaneously, a new method was felt to be developed using RP-HPLC method. Several trails were performed to optimize using various mixtures of solvents as mobile phase. Optimized trial was chosen considering the parameters such as theoretical plates, resolution and retention time.

\section{Preparation of buffer and mobile phase}

\section{Preparation of buffer}

Weigh accurately 3.5 gms of $\mathrm{KH}_{2} \mathrm{PO}_{4}$ mixed in $1 \mathrm{~L}$ of HPLC water. $\mathrm{pH}$ was adjusted up to 3.0. Final solution was subjected to filtration through $0.44 \mu \mathrm{m}$ membrane filter and was sonicated for 10 minutes.

\section{Preparation of the mobile phase}

$0.5 \mathrm{~L}(50 \%)$ of above buffer solution was mixed with $0.5 \mathrm{~L}(50 \%)$ of Methanol HPLC. It was then degassed in a sonicator for around 10 minutes and subjected to filtration through $0.45 \mu$ filter under vacuum filtration. The same solution was used as diluents.

Preparation of metoprolol and Atorvastatin solutions

\section{Standard Solution Preparation:}

$50 \mathrm{mg}$ of Metoprolol and $10 \mathrm{mg}$ of Atorvastatin working standard were weighed accurately and transferred into a $100 \mathrm{ml}$ clean dry VF to which $7 \mathrm{~mL}$ of diluent was added and sonicated to dissolve completely. The volume was madeup to the mark with same solvent after which $1.5 \mathrm{ml}$ of this solution was pipetted into a $10 \mathrm{ml} \mathrm{VF}$ and diluted up to the mark with diluent.

\section{Sample Solution Preparation:}

10 tablets of MET XL ATF, weighed accurately, crushed and powder containing equivalent amount of $50 \mathrm{mg}$ of Metoprolol and $10 \mathrm{mg}$ Atorvastatin sample were transfered into a $100 \mathrm{~mL}$ clean dry VF to which $7 \mathrm{~mL}$ of diluent was added and sonicated to dissolve completely and made the volume up to the mark with the mobile phase and filtered through 0.45 micron Injection filter after which $1.5 \mathrm{ml}$ of this solution was pipetted into a $10 \mathrm{ml} \mathrm{VF}$ and diluted using diluent.

\section{Procedure}

Mixture of phosphate buffer $\mathrm{pH} 3$ and methanol in the ratio $50: 50 \% \mathrm{v} / \mathrm{v}$ was used as mobile phase which was injected into the system for 30 minutes prior to injecting the prepared solutions of standard as well as sample. Detection of the drug was achieved at the wavelength of $230 \mathrm{~nm}$ at $25^{\circ} \mathrm{C}$. After several trials, method was optimized followed by validation of the method considering various validation parameters.

\section{RESULTS AND DISCUSSION}

In the developed method, separation mode was isocratic and the column used to achieve the separation was Inertsil ODS (4.6 x 250mm) with particle size of $5.0 \mu \mathrm{m}$. Binary solvent was used as mobile phase which is a mixture of Phosphate buffer pH3 and methanol in equal ratio. Flow rate was maintained at $1 \mathrm{ml} / \mathrm{min}$ and runtime of $10 \mathrm{~min}$ with injection volume of $20 \mu \mathrm{l}$ at ambient temperature. The peaks obtained had good resolution and retention time of 2.478 mins for metoprolol and 4.169 for Atorvastatin respectively. The chromatogram of the optimized trial is shown in figure 3 . 


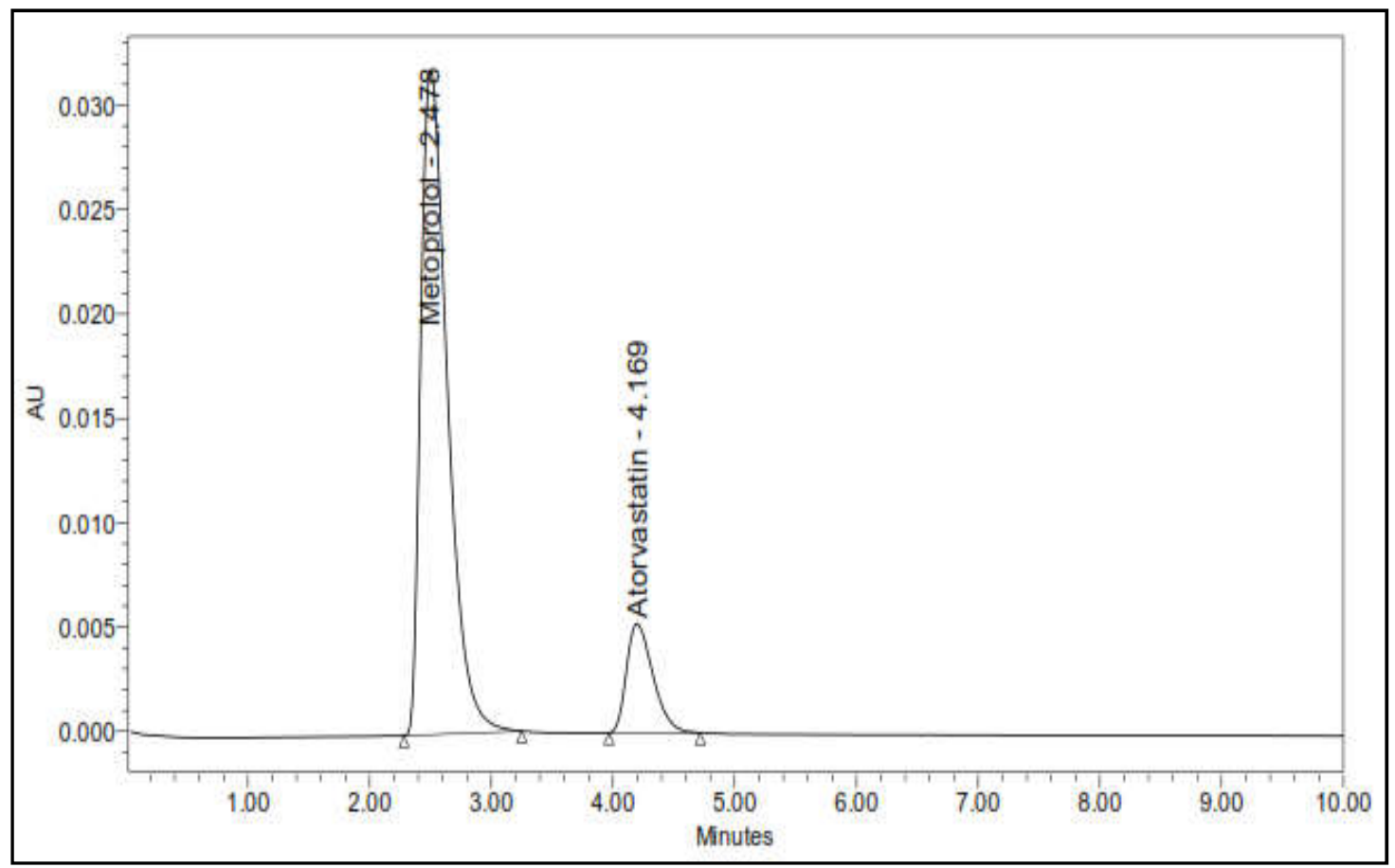

Figure 3: Chromatogram of the optimized trial

\section{System suitability}

Once the column was equilibrated, theoretical plates, asymmetric factor and resolution were evaluated by injecting the standard as well as sample solutions respectively into the chromatographic system and recorded the responses which determines the suitability of the chromatographic system for the analysis. The results are shown in the table 1.

\section{TABLE 1: RESULTS OF SYSTEM SUITABILITY PARAMETERS}

\begin{tabular}{|c|c|c|c|c|c|c|c|}
\hline S.No & Name & $\begin{array}{c}\text { RT } \\
(\mathbf{m i n})\end{array}$ & $\begin{array}{c}\text { Area } \\
(\boldsymbol{\mu V} \mathbf{s e c})\end{array}$ & $\begin{array}{c}\text { Height } \\
(\boldsymbol{\mu V})\end{array}$ & $\begin{array}{c}\text { USP } \\
\text { resolution }\end{array}$ & $\begin{array}{c}\text { USP } \\
\text { tailing }\end{array}$ & $\begin{array}{c}\text { USP plate } \\
\text { count }\end{array}$ \\
\hline 1 & Metoprolol & 2.478 & 536575 & 32710 & & 1.43 & 5584.11 \\
\hline 2 & Atorvastatin & 4.169 & 85809 & 5298 & 4.07 & 1.38 & 6560.51 \\
\hline
\end{tabular}

\section{Validation of the method}

The proposed method was validated by evaluating various validation parameters such as specificity, linearity, accuracy and precision, detection and quantitation limit, robustness as well as stability of the method. Evaluation was done following the $\mathrm{ICH}$ guidelines. The method was specific as there were no interferences found due to the excipients. Linearity results obtained had good correlation and the assay result obtained was good and is shown in table 2 . 
TABLE 2: ASSAY RESULTS

\begin{tabular}{|c|c|c|}
\hline & Label Claim (mg) & \% Assay \\
\hline Metoprolol & 50 & 100.03 \\
\hline Atorvastatin & 10 & 99.82 \\
\hline
\end{tabular}

\section{Linearity}

The linearity range was found to lie from $25 \mu \mathrm{g} / \mathrm{ml}$ to $125 \mu \mathrm{g} / \mathrm{ml}$ of Metoprolol, $5 \mu \mathrm{g} / \mathrm{ml}$ to $25 \mu \mathrm{g} / \mathrm{ml}$ of Atorvastatin. Correlation coefficient was observed to be greater than 0.999 for both the drugs. The absorbance values for both the drugs and their calibration curve data are shown in table 3 and the linearity graphs are shown in figure 4 and 5 respectively.

TABLE 3: RESULTS OF LINEARITY

\begin{tabular}{|c|c|c|c|c|}
\hline \multirow{2}{*}{ S. No. } & \multicolumn{2}{|c|}{ Metoprolol } & \multicolumn{2}{c|}{ Atorvastatin } \\
\cline { 2 - 5 } & Concentration $(\boldsymbol{\mu g} / \mathbf{m l})$ & Area & Concentration $(\boldsymbol{\mu g} / \mathbf{m l})$ & Area \\
\hline 1 & 25 & 177826 & 5 & 28052 \\
\hline 2 & 50 & 357746 & 10 & 56700 \\
\hline 3 & 75 & 539448 & 15 & 85185 \\
\hline 4 & 100 & 717271 & 20 & 113978 \\
\hline 5 & 125 & 890665 & 25 & \\
\hline Slope $(\mathrm{m})$ & 7140.8 & & 5782 & 1154 \\
\hline Intercept & 1030.3 & & 0.999 \\
\hline $\mathrm{R}^{2}$ & 0.999 & & \\
\hline
\end{tabular}

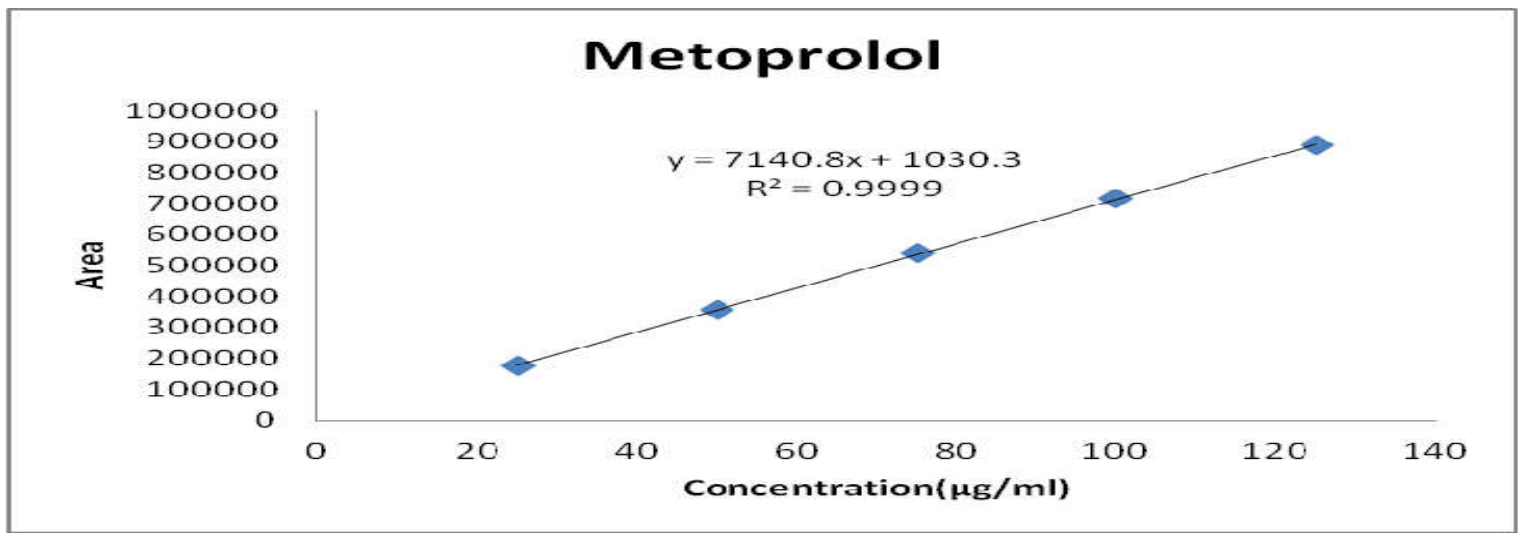

Figure 4: Calibration graph for Metoprolol 


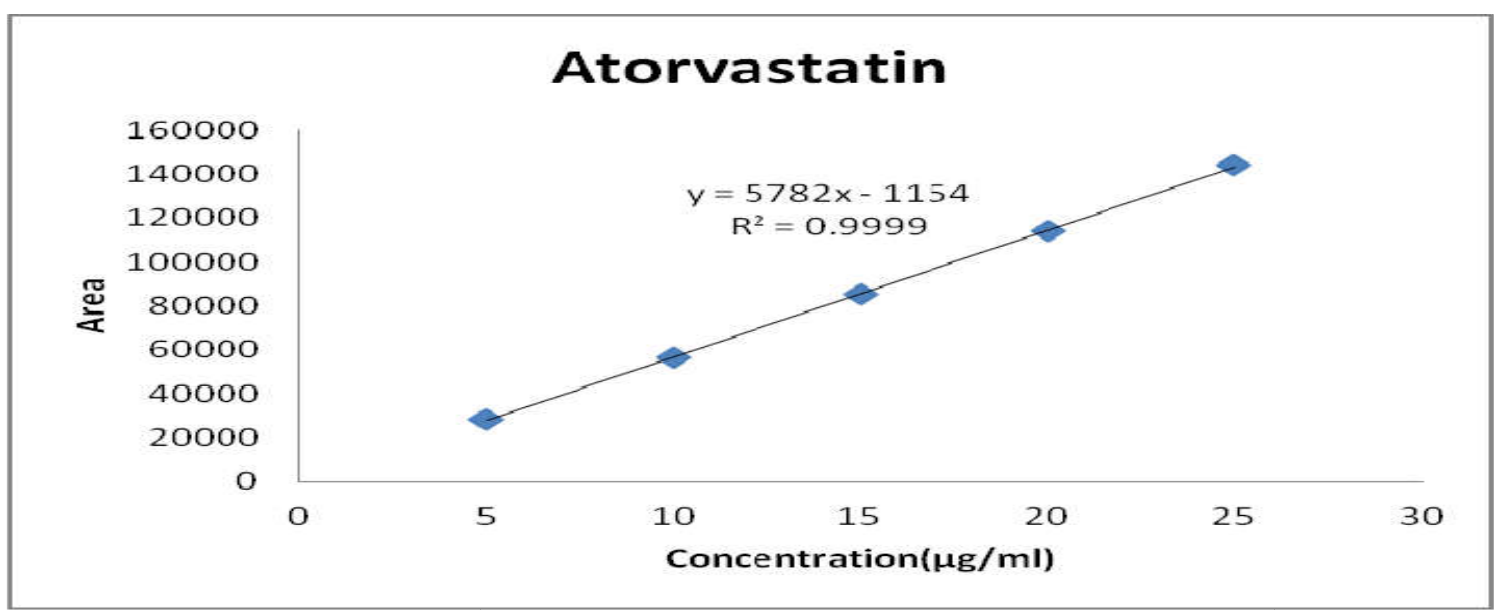

Figure 5: Calibration graph for Atorvastatin

\section{Accuracy}

Sample solutions at different concentrations (50\%, $100 \%$, and 150\%) were prepared and these concentration samples were spiked into the chromatographic system in triplicates and response were recorded. The \% recovery was calculated and the method was found to be accurate as the results were within the limits. Accuracy results are shown in table 4.

TABLE 4: ACCURACY RESULTS

\begin{tabular}{|c|c|c|c|c|c|}
\hline$\%$ Concentration & Area & $\begin{array}{c}\text { Amount Added } \\
\text { (mg) }\end{array}$ & $\begin{array}{l}\text { Amount } \\
\text { Found } \\
\text { (mg) }\end{array}$ & \% Recovery & $\begin{array}{c}\text { Mean } \\
\text { Recovery }\end{array}$ \\
\hline \multicolumn{6}{|c|}{ Results for metoprolol } \\
\hline $50 \%$ & 267451.7 & 25 & 24.96 & 99.82 & \multirow{3}{*}{100.03} \\
\hline $100 \%$ & 532332.3 & 50 & 49.67 & 99.34 & \\
\hline $150 \%$ & 811114.3 & 75 & 75.68 & 100.91 & \\
\hline \multicolumn{6}{|c|}{ Results for Atorvastatin } \\
\hline $50 \%$ & 42711.7 & 5 & 4.99 & 99.83 & 99.82 \\
\hline $100 \%$ & 85512 & 10 & 9.99 & 99.93 & \\
\hline $150 \%$ & 127978.3 & 15 & 14.96 & 99.71 & \\
\hline
\end{tabular}

respectively and injecting into the chromatographic

\section{Precision}

Precision of the method was determined by evaluating the repeatability and intermediate precision/ruggedness. The was done by preparing $75 \mathrm{ppm}$ of Metoprolol and $15 \mathrm{ppm}$ Atorvastatin system six times. Their responses were recorded and the $\%$ RSD was calculated for metoprolol and Atorvastatin respectively and the results were found to be within the limits. The results are presented in table 5 and 6. 
TABLE 5: REPEATABILITY RESULTS

\begin{tabular}{|c|c|c|}
\hline \multirow{2}{*}{ Injection } & \multicolumn{2}{|c|}{ Area } \\
\cline { 2 - 3 } & Metoprolol & Atorvastatin \\
\hline Injection-1 & 536587 & 85514 \\
\hline Injection-2 & 536645 & 85722 \\
\hline Injection-3 & 534973 & 85615 \\
\hline Injection-4 & 539939 & 85728 \\
\hline Injection-5 & 538130 & 85268 \\
\hline Injection-6 & 539250 & 85258 \\
\hline Average & 537587.3 & 85517.5 \\
\hline Standard Deviation & 1860.8 & 212.2 \\
\hline \%RSD & 0.3 & 0.2 \\
\hline
\end{tabular}

TABLE 6: INTERMEDIATE PRECISSION RESULTS

\begin{tabular}{|c|c|c|}
\hline \multirow{2}{*}{ Injection } & \multicolumn{2}{|c|}{ Area } \\
\cline { 2 - 3 } & Metoprolol & Atorvastatin \\
\hline Injection-1 & 530543 & 85499 \\
\hline Injection-2 & 539435 & 85366 \\
\hline Injection-3 & 530808 & 85790 \\
\hline Injection-4 & 534588 & 85997 \\
\hline Injection-5 & 531979 & 85525 \\
\hline Injection-6 & 532150 & 85121 \\
\hline Average & 533250.5 & 85549.7 \\
\hline Standard Deviation & 3351.5 & 309.4 \\
\hline \%RSD & 0.6 & 0.4 \\
\hline
\end{tabular}

\section{Detection and quantitiation limit}

For limit of detection and quantitation, the lowest concentration of the sample was prepared with respect to the base line noise and measured the signal to noise ratio. The chromatograms of LOD and LOQ are shown in figure 6 and 7 where as the results are shown in table 7. 


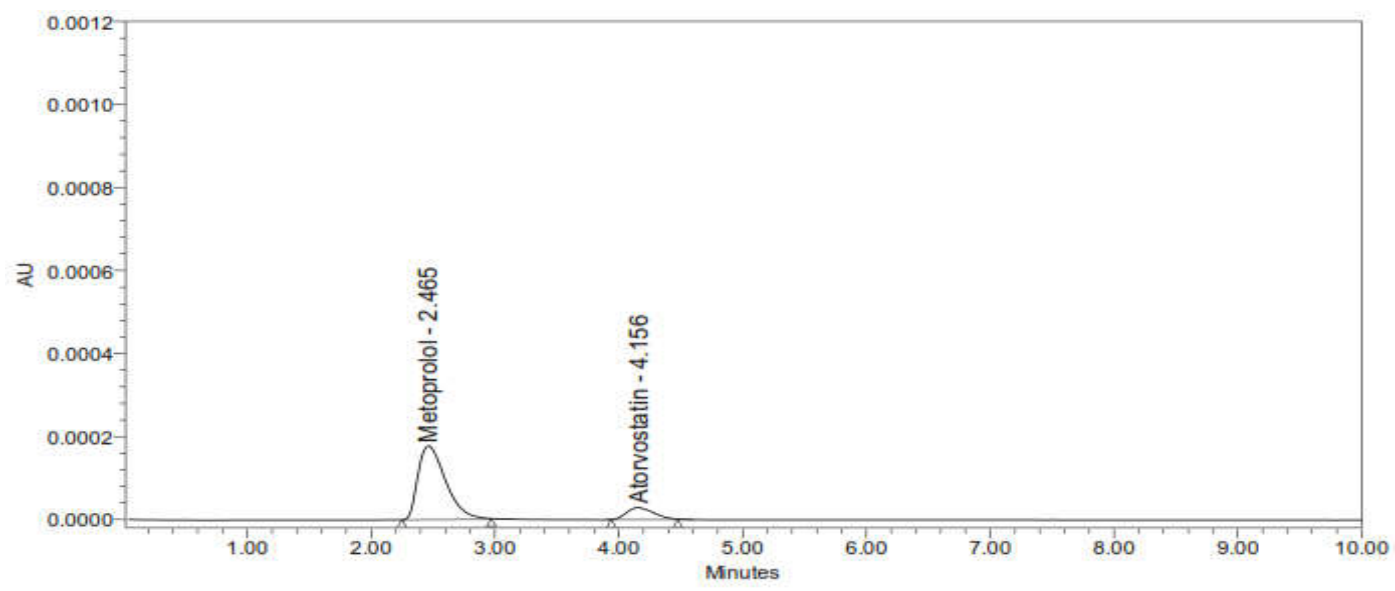

Figure 6: Chromatogram of Metoprolol, Atorvastatin showing LOD

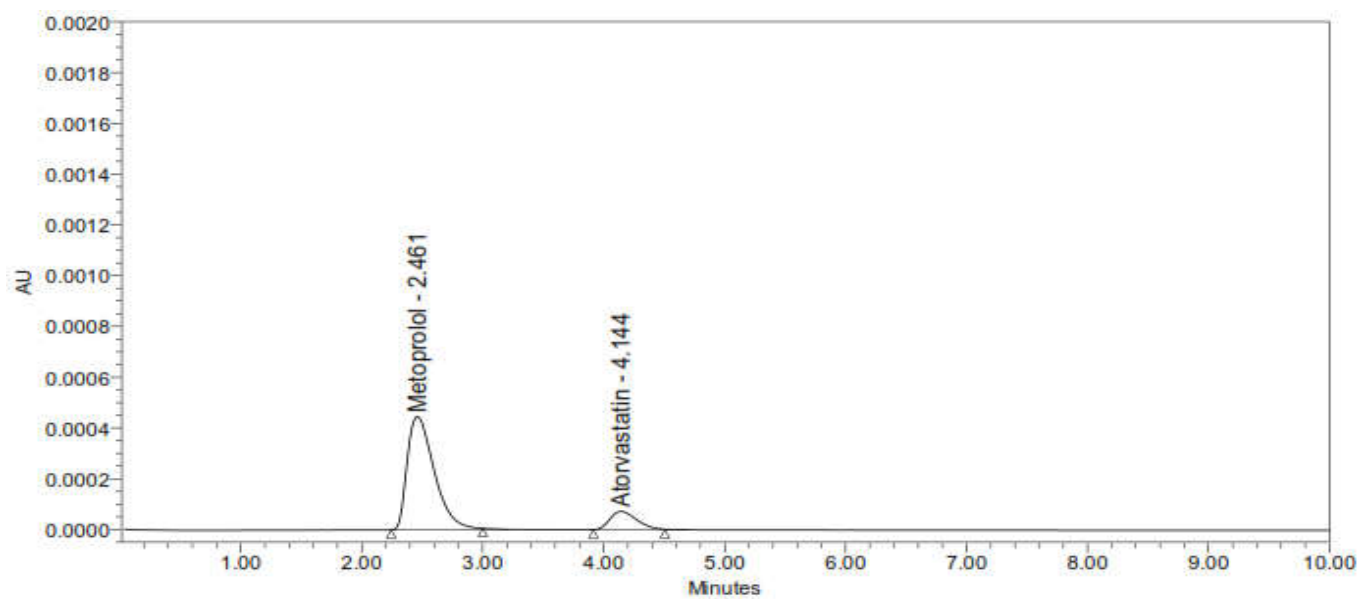

Figure 7: Chromatogram of Metoprolol, Atorvastatin showing LOQ

TABLE 7: DETECTION AND QUANTITATION LIMIT RESULTS

\begin{tabular}{|l|c|c|c|}
\hline Drug name & Baseline noise $(\boldsymbol{\mu V})$ & Signal obtained $(\boldsymbol{\mu V})$ & S/N ratio \\
\hline \multicolumn{7}{|c|}{ Results of LOD } \\
\hline Metoprolol & 58 & 174 & 3.00 \\
\hline Atorvastatin & 58 & 173 & 2.98 \\
\hline \multicolumn{7}{|c|}{ Results of LOQ } \\
\hline Metoprolol & 58 & 579 & 9.98 \\
\hline Atorvastatin & 58 & 580 & 10.00 \\
\hline
\end{tabular}

\section{ROBUSTNESS}

The standard and sample solution of Metoprolol and Atorvastatin were injected by changing the conditions of chromatography such as flow rate and mobile phase composition. No significant variation was observed in the parameters such as resolution, tailing factor, asymmetric factor, and plate count. Results are shown in table 8 and 9 and their respective chromatograms are depicted in figure 811. 


\section{Variation in flow rate}

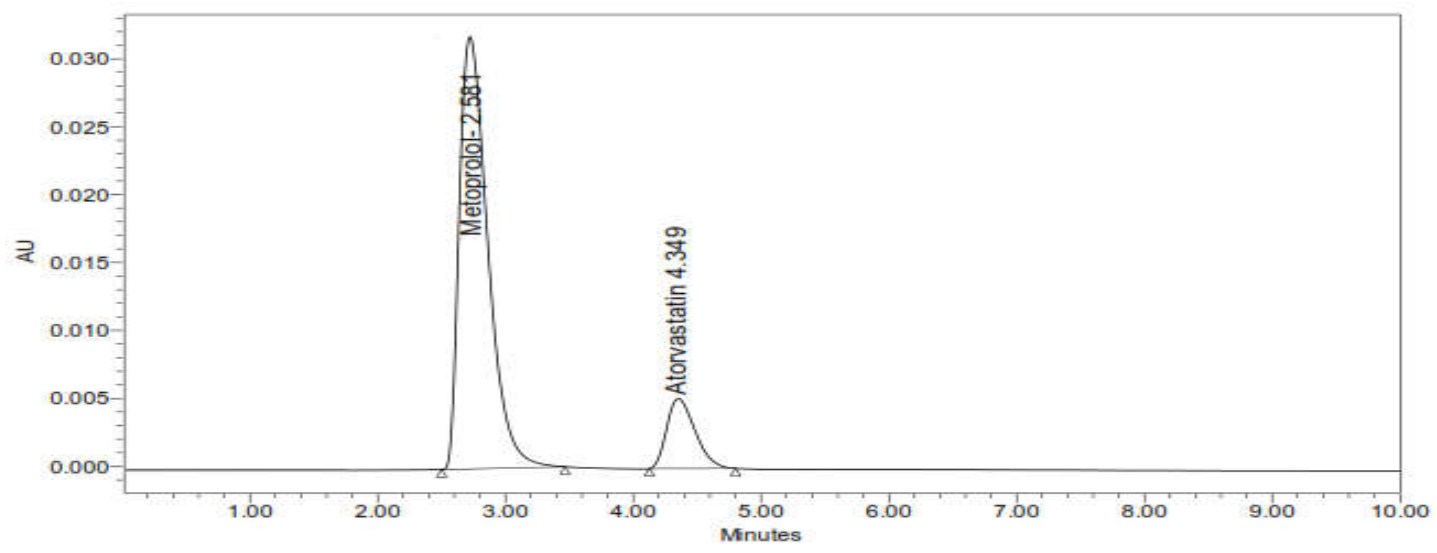

Figure 8: Chromatogram (less flow)

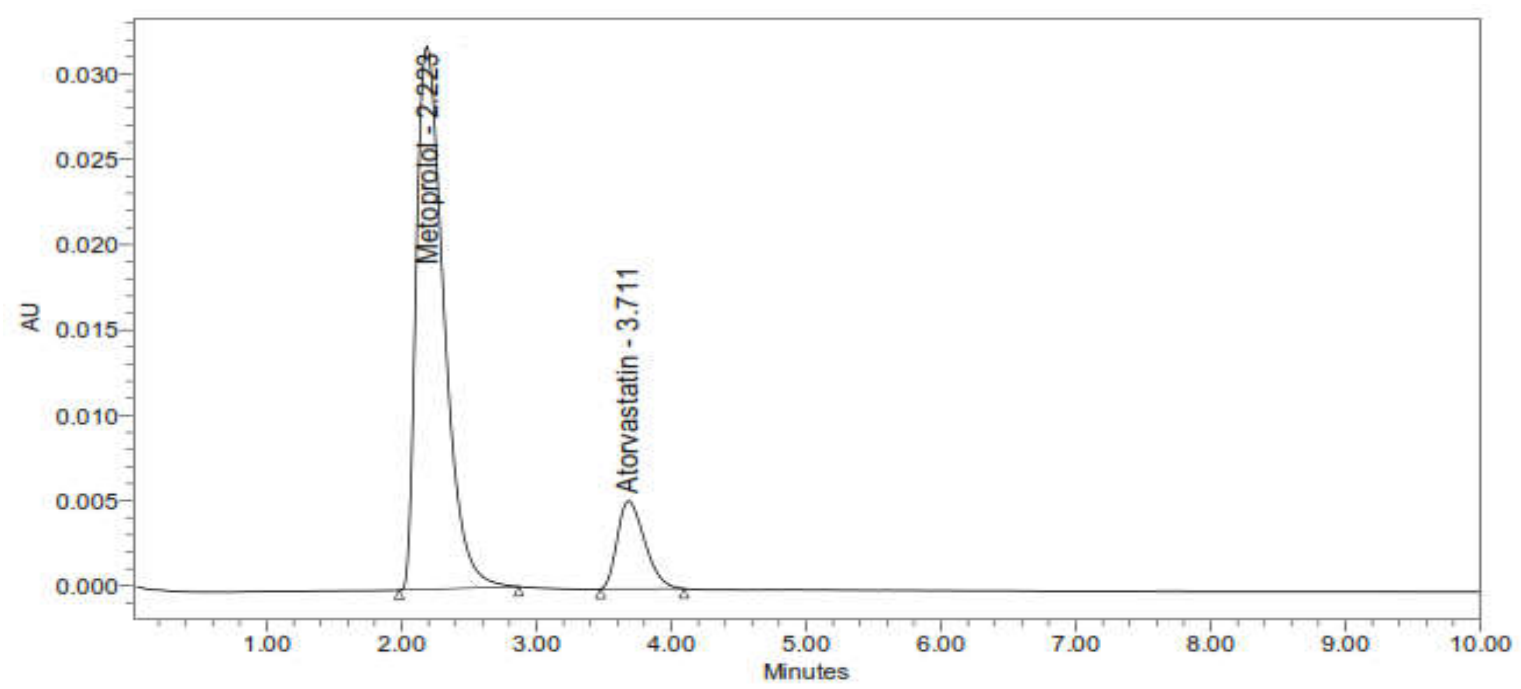

Figure 9: Chromatogram (more flow)

TABLE 8: RESULTS FOR VARIATION IN FLOW RATE

\begin{tabular}{|c|c|c|c|c|c|}
\hline \multirow{2}{*}{ S. No } & \multirow{2}{*}{$\begin{array}{c}\text { Flow Rate } \\
(\mathbf{m l} / \text { minutes })\end{array}$} & \multicolumn{3}{|c|}{ System Suitability Results } \\
\cline { 3 - 6 } & & USP Tailing & USP Plate Count & USP Tailing & $\begin{array}{c}\text { USP Plate } \\
\text { Count }\end{array}$ \\
\cline { 3 - 6 } & & 1.42 & 5615.00 & 1.28 & 6652.00 \\
\hline 1 & 0.9 & 1.43 & 5584.11 & 1.38 & 6560.51 \\
\hline 2 & 1 & 1.42 & 5611.61 & 1.24 & 6503.15 \\
\hline 3 & 1.1 & & & & \\
\hline
\end{tabular}


Variation of mobile phase organic composition

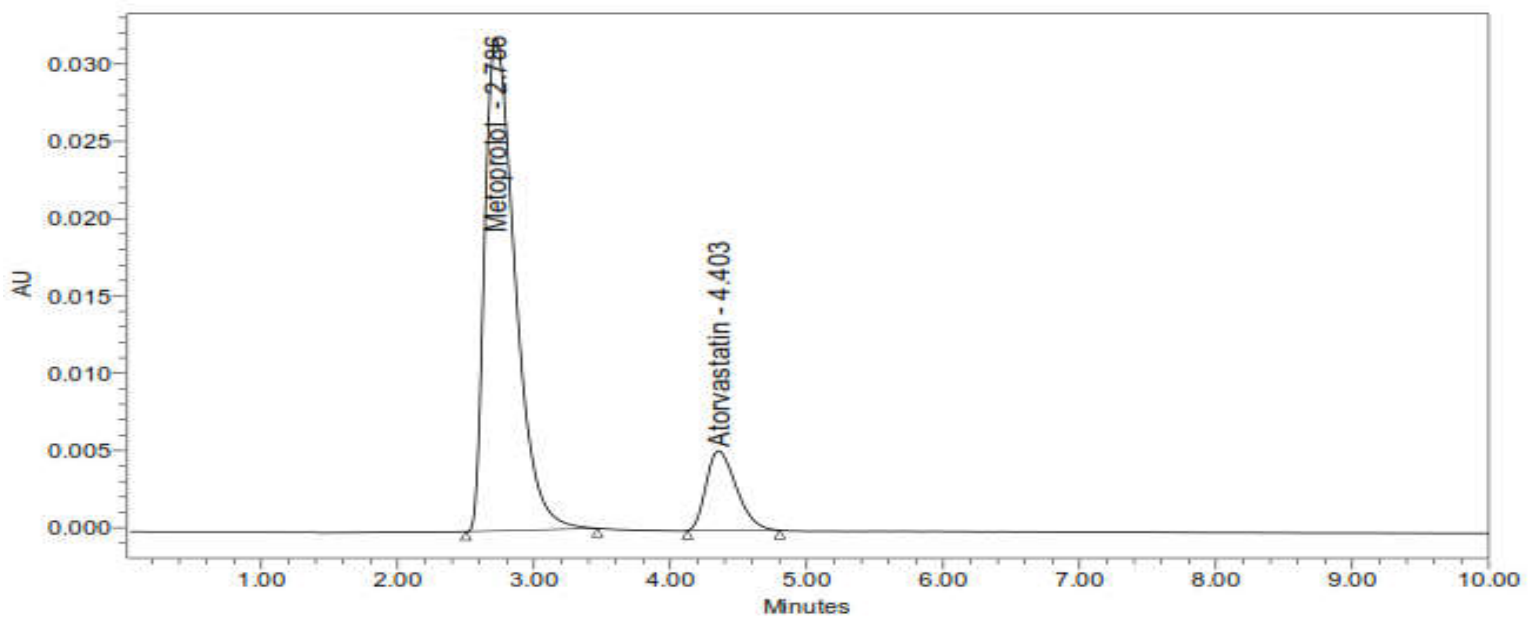

Figure 10: Chromatogram (less organic composition)

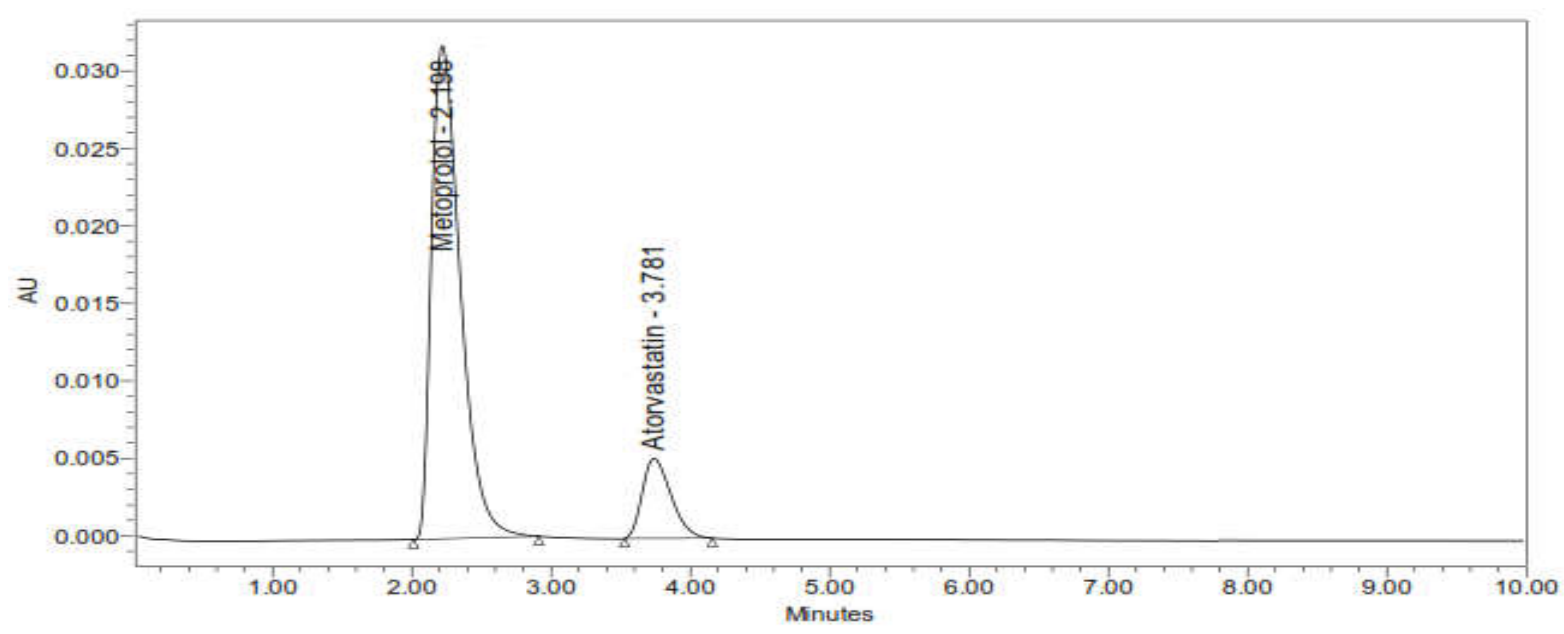

Figure 11: Chromatogram (more organic composition)

TABLE 9: RESULTS FOR VARIATION OF MOBILE PHASE ORGANIC COMPOSITION

\begin{tabular}{|c|c|c|c|c|c|}
\hline \multirow{2}{*}{ S. No } & \multirow{2}{*}{\begin{tabular}{c} 
Change in Organic \\
Composition in the \\
\cline { 3 - 6 }
\end{tabular}} & \multicolumn{3}{|c|}{ Metoprolol } & \multicolumn{2}{|c|}{ Atorvastatin } \\
\cline { 3 - 6 } & Mobile Phase & USP Tailing & USP Plate Count & USP Tailing & $\begin{array}{c}\text { USP Plate } \\
\text { Count }\end{array}$ \\
\cline { 5 - 6 } & $10 \%$ less & 1.37 & 5577.00 & 1.15 & 6337.00 \\
\hline 1 & *Actual & 1.43 & 5584.11 & 1.38 & 6560.51 \\
\hline 3 & $10 \%$ more & 1.46 & 5625.00 & 1.28 & 6720.00 \\
\hline
\end{tabular}

\section{STABILITY OF THE METHOD}

The developed method to be stable was evaluated by adopting degradation studies of the metoprolol as well as Atorvastatin in presence of various stress conditions such as acid, base, peroxide, thermal degradation and photo degradation. The chromatograms of various degradation studies are shown in figure 12-16 and the results are depicted in table 10 . 


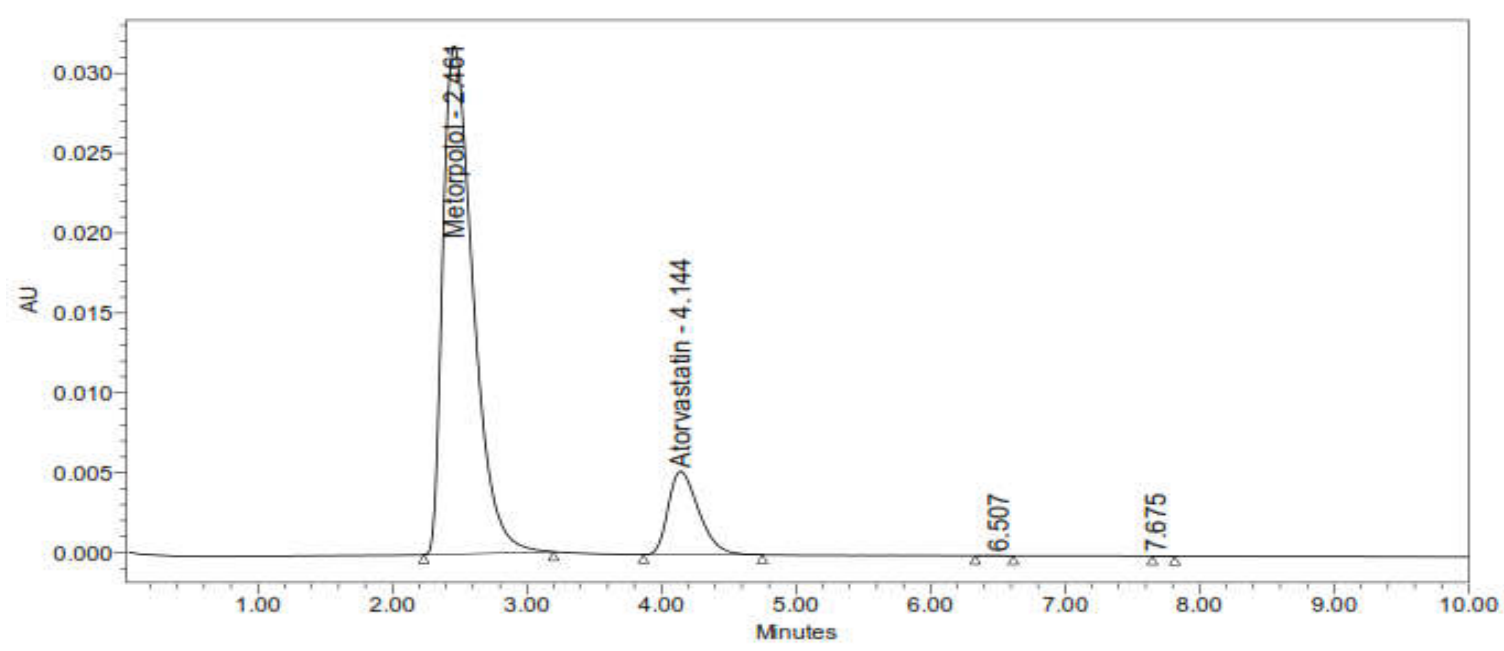

Figure 12: Acid degradation

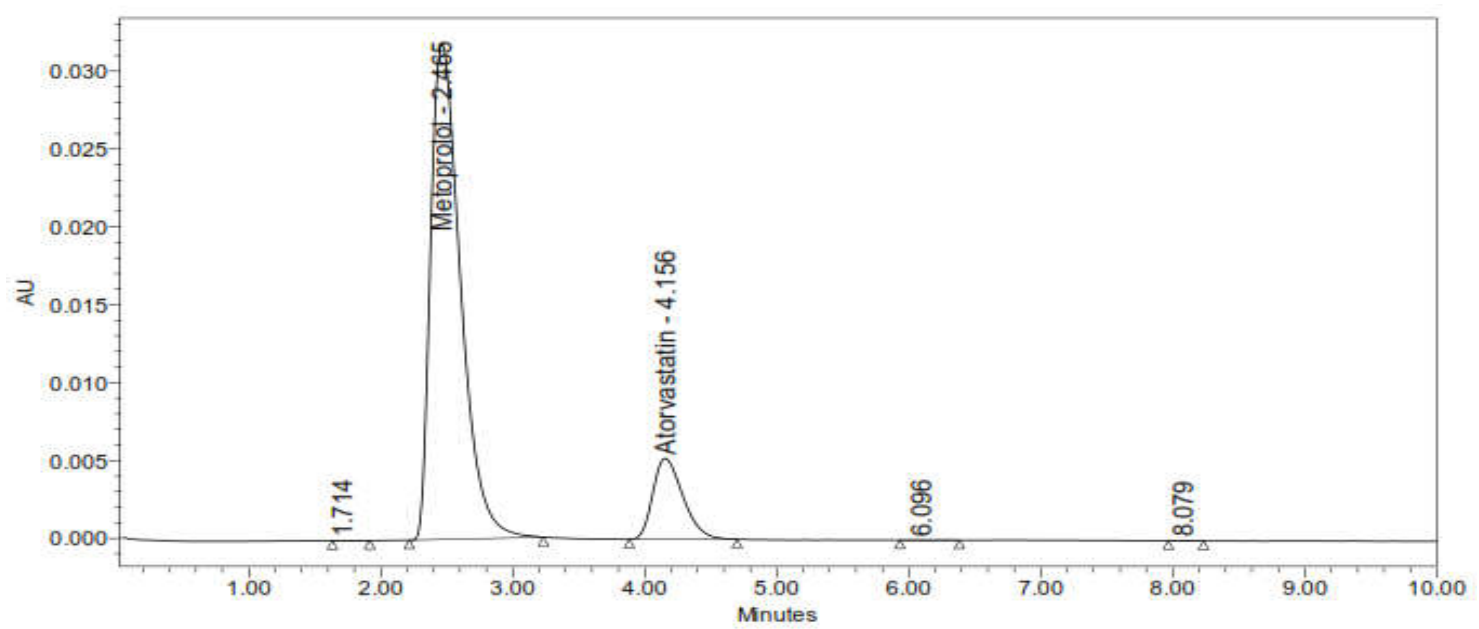

Figure 13: Base degradation

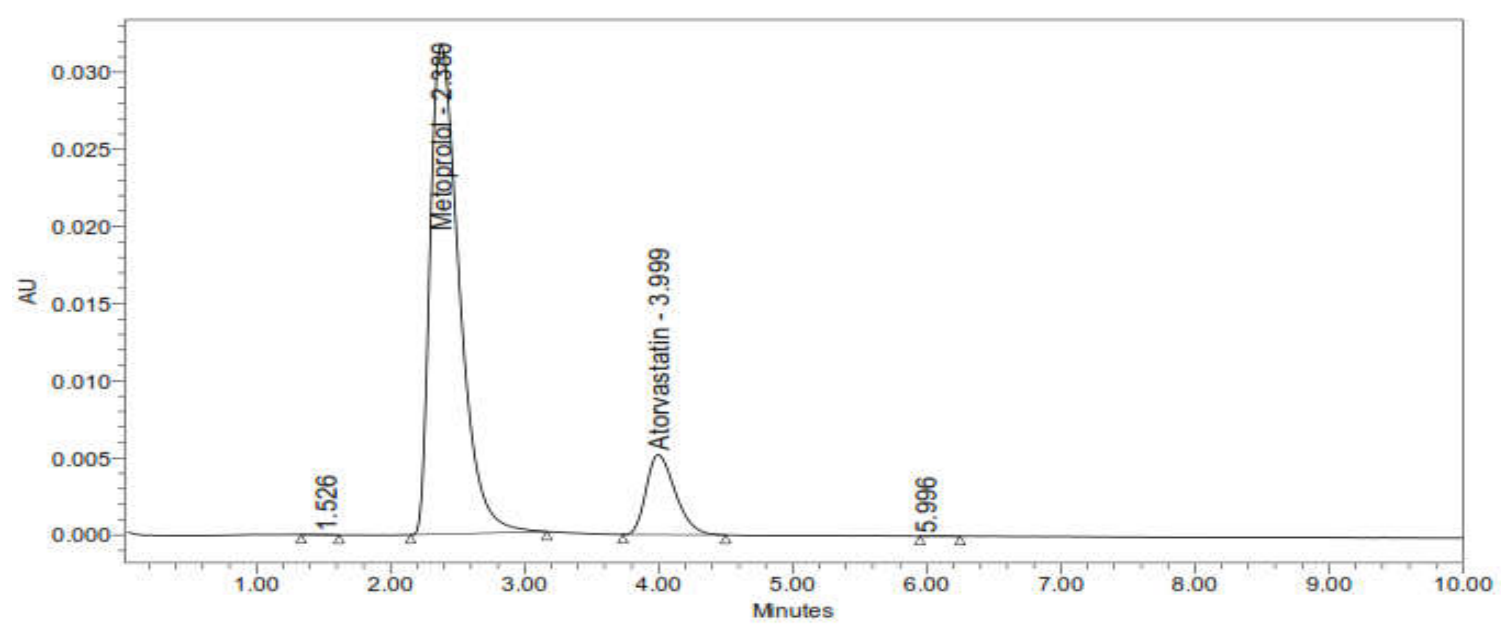

Figure 14: Peroxide degradation 


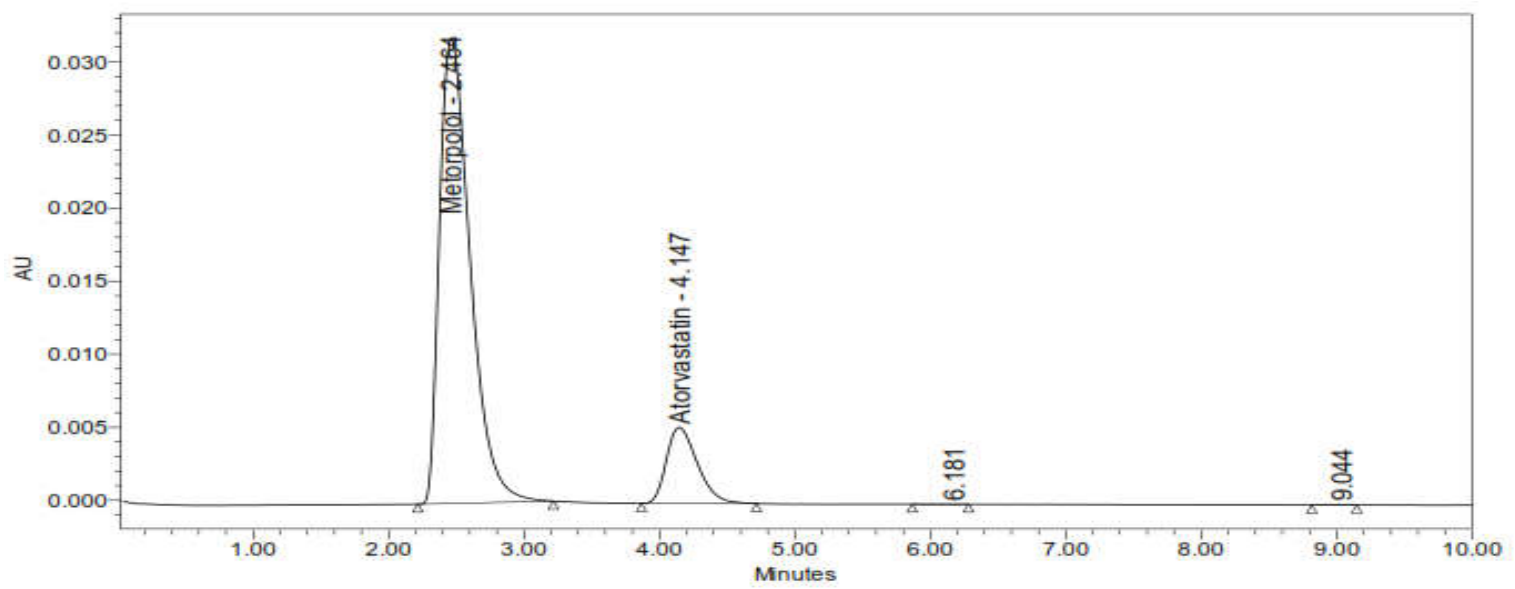

Figure 15: Thermal degradation

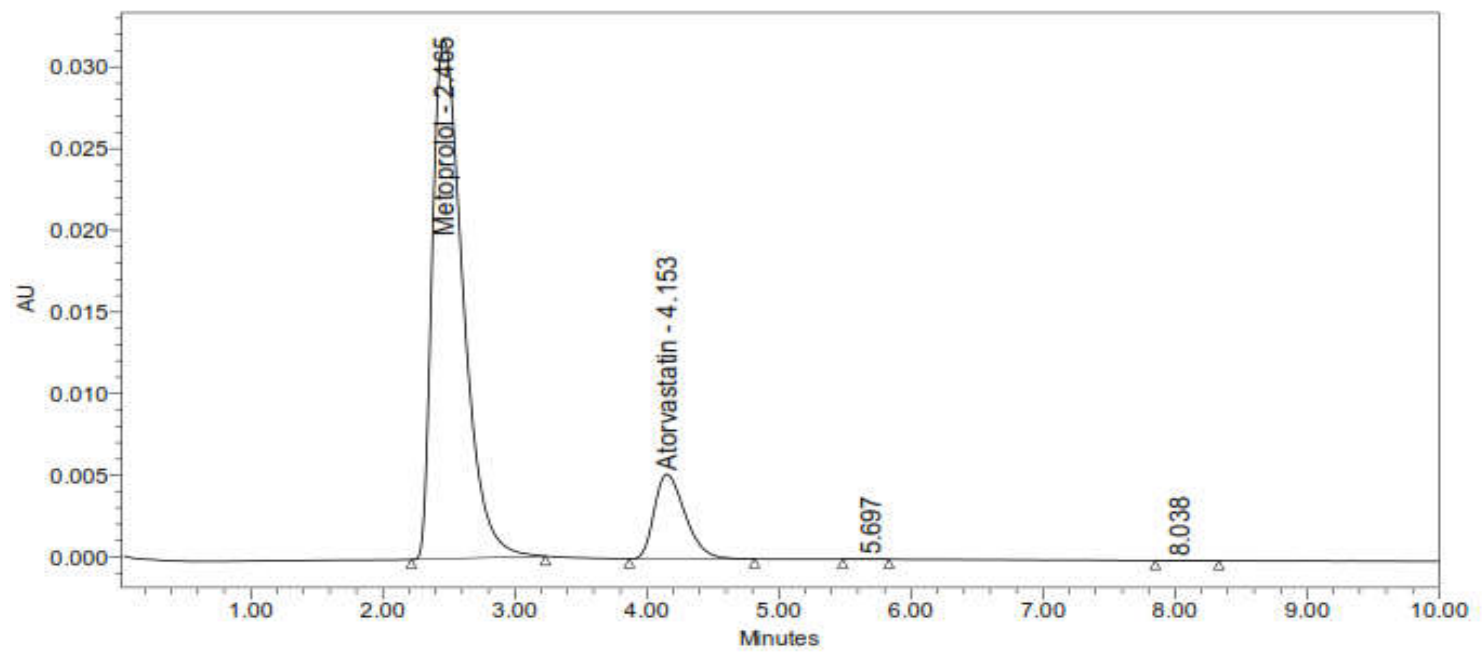

Figure 16: Photo degradation

TABLE 10: RESULTS FOR STABILITY OF METOPROLOL AND ATORVASTATIN

\begin{tabular}{|c|c|c|c|c|}
\hline \multirow{2}{*}{ Sample Name } & \multicolumn{2}{|c|}{ Metoprolol } & \multicolumn{2}{c|}{ Atorvastatin } \\
\cline { 2 - 5 } & Area & \% Degraded & Area & \%egraded \\
\hline Standard & 534777.3 & & 85398.3 & 4.56 \\
\hline Acid & 496035 & 7.24 & 80134 & 6.16 \\
\hline Base & 499639 & 6.57 & 78314 & 8.30 \\
\hline Peroxide & 479014 & 10.43 & 80534 & 5.70 \\
\hline Thermal & 504407 & 5.68 & 77687 & 9.03 \\
\hline
\end{tabular}
and stable analytical method for the estimation of

\section{CONCLUSION}

The present research analytical study was aimed to develop a simple, precise, accurate, robust metoprolol and atorvastatin simultaneously and validate it by RP-HPLC method in tablet dosage 
form. The chromatographic separation was clear at the flow rate of $1 \mathrm{ml} / \mathrm{min}$, and analysis time of 10.0 min, UV detection was at $244 \mathrm{~nm}$. The assay for metoprolol and Atorvastatin were found to be 100.03 and 99.82 respectively. The linearity results of the developed method was greater than 0.999 . From the recovery studies, the method was found to be accurate as the $\%$ recovery of the drugs were within the acceptable range. From the forced degradation studies, the method was found to be stable as the results were NMT $15 \%$. Therefore, from the results obtained, it can be concluded that this can be employed for estimation of Atorvastatin and metoprolol in other dosage forms.

\section{ACKNOWLEDGEMENT}

The authors are thankful to Mr. MD Muzaffar ur Rehman for helping in the preparation of manuscript.

\section{REFERENCES}

1. Wallace AW, Au S, Cason BA. Perioperative $\beta$ blockade: atenolol is associated with reduced mortality when compared to metoprolol. Anesthesiology. 2011;114(4):824-36.

2. Åblad B, Borg KO, Carlsson E, Ek L, Johnsson G, Malmfors T, Regårdh CG. A survey of the pharmacological properties of metoprolol in animals and man. Acta pharmacologica et toxicologica. 1975;36:7-23.

3. Gómez-Moreno G, Guardia J, Cutando A, Calvo-Guirado JL. Pharmacological interactions of vasoconstrictors. Med Oral Patol Oral Cir Bucal. 2009;14(1):E20-7.

4. Lea AP, McTavish D. Atorvastatin. Drugs. 1997;53(5):828-47.

5. Schwartz GG, Olsson AG, Ezekowitz MD, Ganz P, Oliver MF, Waters D, Zeiher A, Chaitman
BR, Leslie S, Stern T, Myocardial Ischemia Reduction with Aggressive Cholesterol Lowering (MIRACL) Study Investigators. Effects of atorvastatin on early recurrent ischemic events in acute coronary syndromes: the MIRACL study: a randomized controlled trial. Jama. 2001;285(13):1711-8.

6. Group AS, Davidson M, McKenney J, Stein E, Schrott H, Bakker-Arkena R, Fayyad R, Black D. Comparison of one-year efficacy and safety of atorvastatin versus lovastatin in primary hypercholesterolemia. The American journal of cardiology. 1997;79(11):1475-81.

7. Jensen BP, Sharp CF, Gardiner SJ, Begg EJ. Development and validation of a stereoselective liquid chromatography-tandem mass spectrometry assay for quantification of S-and Rmetoprolol in human plasma. Journal of Chromatography B. 2008;865(1-2):48-54.

8. Ma L, Dong J, Chen XJ, Wang GJ. Development and validation of atorvastatin by LC-ESI-MS and application in bioequivalence research in healthy Chinese volunteers. Chromatographia. 2007; 65(11-12):737-41.

9. Brijesh S, Patel DK, Ghosh SK. Development of reverse-phase HPLC method for simultaneous analysis of metoprolol succinate and hydrochlorothiazide in a tablet formulation. Tropical Journal of Pharmaceutical Research. $2009 ; 8(6)$.

10. Bullen WW, Miller RA, Hayes RN. Development and validation of a highperformance liquid chromatography tandem mass spectrometry assay for atorvastatin, orthohydroxy atorvastatin, and para-hydroxy atorvastatin in human, dog, and rat plasma. 
Journal of the American Society for Mass Spectrometry. 1999; 10(1):55-66.

11. Bhamare PC, Bari SB, Natarajan S, Patil AA, Patil SH, Shirode PT. Development and validation of a precise single stability indicating HPLC method for determinations of Metformin hydrochloride and Fenofibrate, in pure form and in pharmaceutical tablets. International Journal of PharmTech Research. 2011; 3(1):505-15.

12. Gomes FP, Garcia PL, Porto Alves JM, Singh AK, Kedor-Hackmann ER, Miritello Santoro MI. Development and validation of stabilityindicating HPLC methods for quantitative determination of pravastatin, fluvastatin, atorvastatin, and rosuvastatin in pharmaceuticals. Analytical letters. 2009; 42(12):1784-804.

13. Jain PS, Patel MK, Bari SB, Surana SJ. Development and validation of HPTLC method for simultaneous determination of amlodipine besylate and metoprolol succinate in bulk and tablets. Indian journal of pharmaceutical sciences. 2012;74(2):152.

14. Chaudhari BG, Patel NM, Shah PB, Modi KP. Development and validation of a HPTLC method for the simultaneous estimation of atorvastatin calcium and ezetimibe. Indian journal of pharmaceutical sciences. 2006; 68(6):793.

15. Kadav AA, Vora DN. Stability indicating UPLC method for simultaneous determination of atorvastatin, fenofibrate and their degradation products in tablets. Journal of pharmaceutical and biomedical analysis. 2008; 48(1):120-6.

16. Modi M, Shah R, Mashru RC. Development and validation of spectrophotometric methods for simultaneous estimation of metoprolol succinate and telmisartan in combined pharmaceutical formulation. International Journal of Pharmaceutical Sciences and Research. 2012 ;3(5):1348.

17. Kulkarni MN, Kshirsagar RV, Sakarkar DM. Development and validation of spectro photometric method for determination of metoprolol succinate. Int $\mathrm{J}$ of Chem Tech Res. 2009;1(4):1273-7.

18. Thamake SL, Jadhav SD, Pishawikar SA. Development and validation of method for simultaneous estimation of Atorvastatin Calcium and Ramipril from capsule dosage form by first order derivative spectroscopy. Asian J Res Chem. 2009; 2(1):52-3.

19. Chitlange SS, Imran M, Sakarkar DM. RPHPLC method for simultaneous estimation of amlodipine and metoprolol in tablet formulation. Asian Journal of Pharmaceutics (AJP): Free full text articles from Asian J Pharm. 2014;2(4).

20. ICH Q2B guideline (1996), Validation of Analytical Procedures: Methodology, Guidance for Industry, 1-10. 